\title{
The Analysis of Determinant Factor of Company Value on Manufacture Company Listed on Indonesia Stock Exchange
}

\author{
Anissa Amalia Mulya ${ }^{1}$, Dicky Arisudhana ${ }^{2}$ \\ \{mulya.anissa@gmail.com ${ }^{1}$, dicky.arisudhana@gmail.com² ${ }^{2}$. \\ Faculty of Economy and Business, Universitas Budi Luhur, Jl. Ciledug Raya, Jakarta, Indonesia ${ }^{1,2}$
}

\begin{abstract}
A high increase in corporate value is a long-term goal that a company should achieve that will be reflected in its stock market price. This study is aimed to analyze the effect of profitability, leverage, firm size, liquidity, debt policy and investment decisions on the value of the company in the food and beverage sub-sector manufacturing company listed on Indonesia Stock Exchange period of 2012-2016. This research is a quantitative research using purposive sampling techniques to determinate the sample. This research obtained 9 (nine) companies from 14 companies. The analysis model used in this research is multiple linear regression models. The research result indicate that profitability and investment decisions have a significant effect, while leverage, firm size, liquidity and debt policy has no significant effect on firm value.
\end{abstract}

Keywords: Profitability, leverage, company size, liquidity, debt policy, investment decision, corporate value

\section{Introduction}

The business sphere plays an important role for development, either by government or by private sector. Many companies improve the quality of their companies in order to be able to compete in the market and attract consumers. The success of a company can only be achieved by good corporate management. One of those is to improve the value of the company, the prosperity of the company owner and the market price of its shares. The value of the company can describe the company situation.

The value of the firm could indicate the level of company success and it could become the investors' perception to valuate a company. In addition, it is usually often associated with stock prices. The value of a company is the amount it receives when a company is sold as a business in operation. Price to book value (PBV) is used as a projection of the value of the stock because it gives an idea of how many investors appreciate a stock.

In the stock market, the stock price of a company often reacts to the publication of the achievement of corporate value. From the source www.cnn.com, the Minister of Trade has issued a regulation since 2015 that prohibits the sale of alcoholic beverages in minimarkets and retailers, which clearly makes the stock price of food and beverage sector dropped, especially the beverage sector, Delta Djakarta (DLTA) and Multi Bintang (MLBI) and this price weakening is taking place throughout 2015. Fluctuations in the share prices of food and beverage manufacturing companies listed on the Indonesia Stock Exchange for two years are presented in the following graph. 


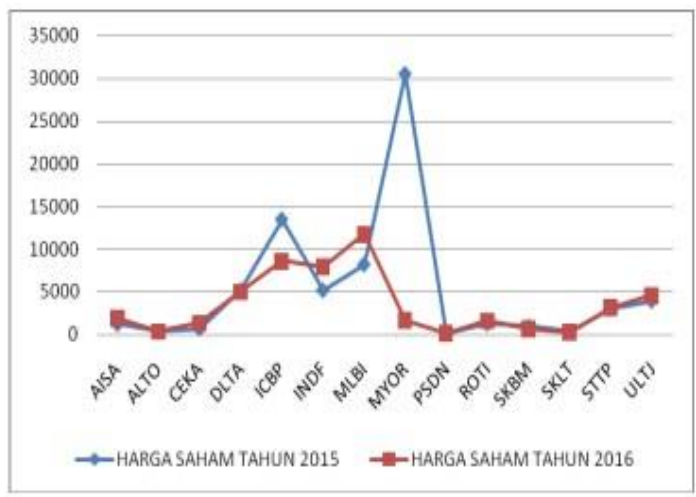

Fig. 1. Stock Price Fluctuation

There are several factors that may affect the value of the firm, such as managerial ownership, , audit committee, institutional ownership, earnings quality, dividend policy, firm size, growth, capital structure, profitability, liquidity, debt policy, interest rate, firm size, investment decisions and etc. This study is a modification of previous research, however the authors, in this study, only limit the variables that affect the value of the company consisted of profitability, leverage, company size, liquidity, debt policy and investment decisions. Subjects that are used in this study is a food and beverage sub-sector manufacturing company listed on the Indonesia Stock Exchange period 2012-2016.

\subsection{Signaling Theory}

Signal theory propounds how a company should give signal toward financial statement users. Signal theory discusses the company's drive to provide information to external parties. The impetus is due to the information asymmetry between management and external parties. Firms can increase company value by reducing asymmetric information. Information asymmetry occurs when management does not convey all financial information as a whole to external parties [1].

\subsection{Firm Value}

Corporate value conceptually can be explained as the value determined by the stock price traded in the capital market [2].According to Wahyudi, Pawestri (2006) in Meidiawati (2016), the market price of the company's shares is formed between the buyer and the seller during transaction because the stock market price is considered as a reflection of the true value of the company's assets [3].

Company value can be measured by a ratio called rating ratio. In this study, the researchers use Price to Book Value Ratio (PBV) as an indicator to measure the value of the company [4]:

$$
\text { PBV }=\frac{\text { Stock price per sheet }}{\text { Book value of stock per sheet }}
$$




\subsection{Profitability}

Profitability is a ratio to assess the ability of companies in the search for profit. This ratio also provides a measure of the effectiveness of a company's management level. This is shown by the profits generated from sales and investment income. In essence, the use of this ratio indicates the efficiency of a company [5]. This study measures profitability by using Return on Asset Ratio (ROA), this ratio measures the company's ability to generate profits based on certain asset levels. Return on Assets is a ratio that sees the extent to which the investment or total assets that have been invested can provide the return of profits as expected [6]. The formula of Return on Asset Ratio (ROA), as follows:

$$
\text { ROA }=\frac{\text { Netprofit }}{\text { Total Assets }}
$$

\subsection{Leverage}

Leverage is the amount of debt used to finance the assets of the company [8]. Companies that have larger debt than equity are said to be companies with high Leverage rates. Leverage ratio aims to analyze the expenditures made in the form of debt and capital composition and the ability of companies to pay interest and other fixed expenses [7].

In this research leverage is proxied by using Debt Ratio. According Sawir (2008), debt ratio is a ratio that shows the proportion between the obligations owned and all owned wealth. Debt Ratio can be calculated by the formula [9]:

$$
\text { Debt Ratio }=\frac{\text { Total debt }}{\text { Total Asset }}
$$

\subsection{Company Size}

According Hermuningsih (2012), firm size (firm size) is an indicator that shows the financial strength of the company. The size of the company is considered capable of affecting the value of the company, because the larger the size or scale of the company, the easier the company to obtain sources of funding both internal and external [10]. According Rahmawati, Topowijono, Sulasmiyati (2015), company size can be seen from the total assets owned by the company. In this study, firm size was assessed by Log of Natural Total Assets to reduce significant differences between small size firms. Company size can be measured by the formula [11], [3]:

$$
\text { Firm size }=\text { LN }(\text { TotalAsset })
$$

\subsection{Liquidity}

According to Moeljadi (2006: 67) in Amanah, Atmanto, Azizah (2014) liquidity is an indicator of the company's ability to remunerate all financial obligations in due time. A high 
level of liquidity indicates that the company has no difficulty paying its liabilities in the short term, so the creditors do not have to worry about giving loan [12]. In this research, liquidity ratio is proxied by using Current Ratio or current liabilities. According Sawir (2008) Current ratio is a comparison between current assets and current liabilities and is the most common measure used to determine the ability of a company to meet its short-term obligations. Current ratio can be calculated by the formula [9]:

$$
\text { Current Ratio }=\frac{\text { Current assets }}{\text { Current liabilities }}
$$

\subsection{Debt Policy}

According to Munawir (2016) debt is all the company's financial policies to other parties that have not been fulfilled, where the debt is a source of funds or capital companies that come from creditors [13]. Brigham and Houston (2011: 78) in Pertiwi, Parengkuan, Tumiwa (2016), stated that debt policy is a policy regarding the decisions taken by a company to run its operations using financial leverage [14]. Debt policies are often measured by using debt ratios that reflect the company's ability to carry out all of its liabilities shown by some of its own capital used to repay debt. According to Harjadi (2013), Debt to Equity is a ratio that measures the extent to which the debt can be covered by own capital. Debt to Equity ratio (DER) can be calculated by the formula [15]:

$$
\text { PER }=\frac{\text { Stock Price per sheet }}{\text { Net profit per sheet }}
$$

\subsection{Investment Decision}

Investment is a commitment to a number of funds or other resources undertaken currently, with the purpose of obtaining future benefits Tandelilin, (2010: 2) in [14]. According to Nadhiroh (2013), investment decisions are provisions made by the company in spending the funds that it has in the form of certain assets with expectation to gain profit in the future. One of the ratios that can be used to determine investment decision is with Price to Earnings Ratio (PER). PER can be used as a proxy for investor expectations and market valuation. The formula used in calculating investment decisions are [16]:

$$
\text { Current Ratio }=\frac{\text { total debt }}{\text { Total equity }}
$$

\subsection{The Effect of Profitability on Corporate Value}

Profitability measures the company's ability to generate profits from business activities. Profitability in this study proxied with ROA is a value that reflects the return of the company from all assets given to the company, this ratio comparison between net profits after tax with total assets owned. The higher this ratio the better the asset productivity in obtaining net profit. This will increase the attractiveness of the company to shareholders or investors so that it can 
affect the value of the company [1]. This supports the research that has been done by Pertiwi, Parengkuan, Tumiwa (2016) which shows that profitability has a significant influence on the value of the company [14].

Hypothesis1:Profitability has a positive effect on Corporate Value.

\subsection{The Effect of Leverage on Corporate Value}

According to Suffah, Riduwan (2016), sources of funding within the company can be obtained from external companies in the form of debt. Leverage shows the ability of a company to meet all the financial obligations of the company in case the company is liquidated. The debt can be used to control the free cash flow excessively by management. Therefore, it can avoid wasted investment and will increase the value of the company. Increasing the debt ratio of a company is a positive signal for investors with the assumption that future cash flow will be maintained [4]. This is in line with research conducted by Utama and Wikuana (2016) which shows that partial leverage gives positive effect significantly on company value.

Hypothesis2: Leverage gives positive effect significantly on company value.

\subsection{The Influence of Company Size on Corporate Value}

Company size is one of the variables considered in determining the value of a company. The size of a company is a total reflection of an organization's assets. Companies themselves are categorized into two types: small-scale companies and large-scale companies. According to Ta'dir, Parengkuan, Taerang (2014), large-scale companies have the convenience to enter the capital market, making it easier for companies to get additional funds. This will be considered as a good prospect for the company so that it will attract investors to invest their capital [17]. This is in line with research conducted by Nurhayati (2013) shows the size of the company has a positive and significant impact on corporate value [18].

Hypothesis 3: Company size has a positive effect on Corporate Value.

\subsection{The Effect of Liquidity on Corporate Value}

High liquidity can show available funds to pay dividends, finance the company's operations and investment so that it makes investors' perceptions better on the performance of the company. This is because companies with high levels of liquidity have large internal funds, so the company also uses its internal funds first to finance its investment before using external financing through debt. This can increase investor's demand for the company's stock increases, resulting in the value of the company will also increase [19]. The results of Putra and Lestari (2016) show that liquidity has a positive effect on firm value [19].

Hypothesis 4: Liquidity has a positive effect on Corporate Value.

\subsection{The Effect of Debt Policy on Corporate Value.}

Managers can use debt as a more trusted signal for investors. This is because companies that increase debt can be viewed as another company with the prospect of the company in the future. So the use of debt is a sign or a positive signal from the company that can make investors appreciate the value of shares greater than the value recorded on the balance sheet company, so that corporate PBV and corporate value is high or increase the value of the company [20]. The results of Pertiwi, Parengkuan, Tumiwa (2016) show debt policy proxyed 
with debt to equity ratio (DER), partially have a significant positive effect on firm value [14]. This is supported by the results of research Purnama (2016) which states debt policy has a significant effect and have a positive relationship direction. Based on the theory of explanation mentioned above, it can be made as follows hypothesis [20]:

Hypothesis 5: Debt Policy has a significant positive effect on firm value.

\subsection{The Influence of Investment Decision on Corporate Value}

Investment decisions are provisions made by the company to spend the funds it has in the form of certain assets with expectation to gain profit in the future [16]. Suroto (2015) stated that managers who managed to create the right investment decisions, then the assets invested will produce optimal performance so as to provide a positive signal to investors who will increase the company's value and value [21]. Pertiwi, Parengkuan, Tumiwa (2016) states that the decision of investment has a positive and significant impact on the value of the company. High investment is a signal of future revenue growth companies. The signal will be considered good news that will affect the perception of investors on the company's performance that will ultimately affect the company's value [14]. Based on that opinion, the researcher proposed the hypothesis:

Hypothesis 6: Investment decisions have a positive effect on firm value.

\section{Methods}

\subsection{Population and Sample}

This study included casual research using a quantitative approach. The object of research in this research is manufacturing companies, food and beverage sub-sector companies listed in Indonesia Stock Exchange period 2012-2016. The data used in this study is secondary data and obtained from the company's financial statements published through the website of Indonesia Stock Exchange (www.idx.co.id). The population in this research are 14 food and beverage sub-sector companies listed on Indonesia Stock Exchange from 2012-2016. And there are 9 research samples companies that fulfill the criteria of the research. Sample selection criteria are as follows:,

Table 1. Sample Criteria Research Table.

\begin{tabular}{ll}
\hline Criteria & Quantity \\
\hline The food and beverage sub-sector is listed on the & \\
Indonesia Stock Exchange for the period 2012- & 14 \\
2016. & \\
Food and beverage companies that do not publish & \\
their full financial statements during the period of & 5 \\
$2012-2016$. & 9 \\
Number of companies used as samples &
\end{tabular}




\section{Result and Discussion}

\subsection{Multiple Linear Regression Analysis}

\subsubsection{Goodness Fit Test}

Table 2. Result of Goodness Fit Test.

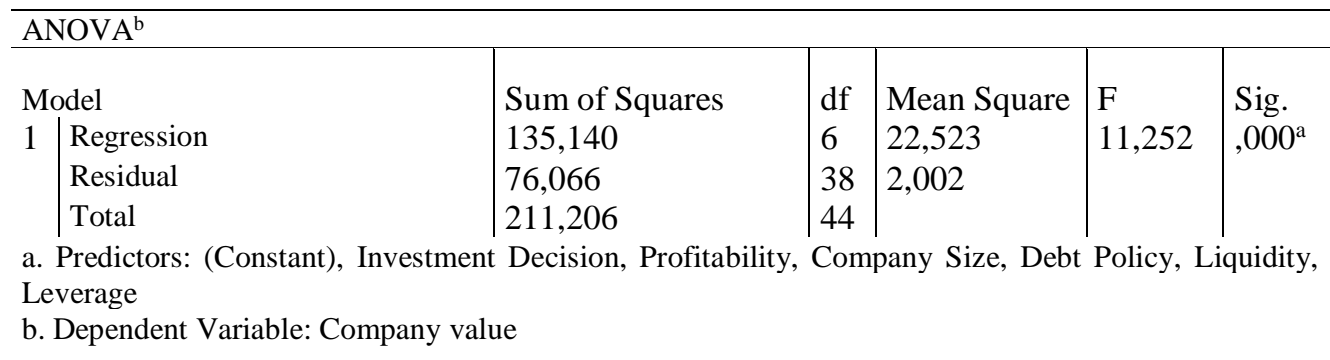

Sig. output is known 0.000. Because Sig output $(0.000)<$ Sig. $\alpha(0.05)$, based on these results it can be concluded that the model is fit or proper to use.

\subsubsection{Determination Coefficient Analysis}

From Table 5above, it can be seen that from the calculation of the adjust value ${ }^{2}$ indicates a number 0.583 it means $58,3 \%$ of the company's value is determined by the variables of Profitability, Leverage, Company Size, Liquidity, Debt Policy and Investment Decision. While the rest equal to $41,7 \%(100 \%-58,3 \%)$ influenced by other factors that are not examined in this research.

\subsubsection{Statistic test $T$}

Table 3. Multiple Linear Regression Test Results.

\begin{tabular}{|c|c|c|c|c|c|c|}
\hline \multirow{2}{*}{\multicolumn{2}{|c|}{ Model }} & \multicolumn{2}{|c|}{$\begin{array}{l}\text { Unstandardized } \\
\text { Coefficients }\end{array}$} & \multirow{2}{*}{$\begin{array}{c}\begin{array}{c}\text { Standardized } \\
\text { Coefficients }\end{array} \\
\text { Beta }\end{array}$} & \multirow[b]{2}{*}{$t$} & \multirow[b]{2}{*}{ Sig. } \\
\hline & & B & Std. Error & & & \\
\hline \multirow[t]{7}{*}{1} & (Constant) & $-2,308$ & 4,213 & &,- 548 & ,587 \\
\hline & Profitability & 16,467 & 4,910 & ,509 & 3,354 & ,002 \\
\hline & Leverage & $-2,304$ & 3,127 &,- 164 &,- 737 & 466 \\
\hline & Firm size & , 081 & ,131 & , 064 & ,623 & ,537 \\
\hline & Liquidity & 259 & 247 & , 173 & 1,051 & ,300 \\
\hline & Debt policy & ,390 & 937 & ,082 & ,416 & 680 \\
\hline & $\begin{array}{l}\text { Investment } \\
\text { decision }\end{array}$ & ,061 & ,022 & ,284 & 2,778 & ,008 \\
\hline
\end{tabular}

Based on table 3, the above output results can be explained as follows:

1. Profitability variable has Sig value. 0,002 (0,002>0,05) and Investment Decision variable has Sig value. 0,008 $(0.008>0.05)$ sot this matter can be stated H01 and H06 are accepted 
and Ha1 and Ha6 are rejected, it means partially Profitability Investment Decision has significant effect to Company Value.

2. Leverage variable has Sig value. 0.466 (0.466>0.05); Size Company Variable has Sig value. 0,537 (0,537<0,05); Liquidity variable has Sig value. $0.300(0.300>0.05)$; and Debt Policy Variables have Sig value. 0.680 (0.680> 0.05), so it can be stated H02, H03, H04, H05 are accepted and Ha2, Ha3, Ha, Ha5 are rejected, it means partially Leverage, Size Company, Liquidity and Debt Policy

\subsubsection{Multiple Linear Regression Equation}

Based on table 3 above can be seen the regression equation, as follows:

$$
\begin{aligned}
& \text { Company Value: } \mathrm{a}+\beta 1 \text { Profitability }+\beta 2 \text { Leverage }+\beta 3 \\
& \text { Company size }+\beta 4 \text { Liquidity }+\beta 5 \text { Debt Policy }+\beta 6 \\
& \text { Investment Decision }+\varepsilon \\
& \text { Company Value: }-2,308+16,467 \text { Profitability- 2,304 } \\
& \text { Leverage }+0,081 \text { Corporate Size }+0,259 \text { Liquidity }+ \\
& 0,390 \text { Debt Policy }+0,061 \text { Investment Decision }+\varepsilon
\end{aligned}
$$

\subsubsection{The Effect of Profitability on Corporate Value}

The result of the first hypothesis analysis shows that profitability partially has a positive and significant effect on Corporate Value. This happens because profitability is a company's ability to generate profits or profits that reflect the success of a company. High profitability will provide a positive signal for investors that the company is in a favorable condition or has the ability to profit, therefore, it could become one of the attractive things for investors to own shares of the company. So the higher value of profitability gained then the higher value of the company. Due to high profitability will provide an indication of good corporate prospects that can trigger investors to increase share demand. Increased stock demand will cause the company's value to increase as well, in line with previous research conducted by Pertiwi, Parengkuan, Tumiwa (2016), but the results of this study are inconsistent with other studies conducted by Moniaga (2013) which show that profitability does not affect the value of the company [22].

\subsubsection{The Effect of Leverage on Corporate Value}

Results of the second hypothesis analysis show that Leverage partially has no significant effect on Corporate Value. Leverage size does not affect Corporate Value because investors not only see how big companies use funding from debt in running their business to increase the value of the company but investors also pay attention to other funding such as funding derived from the company's equity. This research is consistent the result of research from Prastika (2012) which resulted in the result that Leverage has no positive effect on Corporate Value [23]. Different things are shown by research conducted Pratama, Wiksuana (2016) which states that leverage has a positive effect on the value of the company[24]. 


\subsubsection{Effect of Company Size on Corporate Value}

The result of the third hypothesis analysis shows that company size partially has no significant effect on Corporate Value. This means that firm size is no longer the concern of investors in making decisions for investment. In investing investors not only review from how much assets of the company but also from other side like financial statement, good name and also dividend policy. This research is consistent with the research of Suwarno, et al (2016) which resulted in the results of research that company size does not have a positive effect on company value. However, the result of Putra and Lestari research (2016) shows a significant positive influence between company variable and firm value [19].

\subsubsection{Liquidity Influence on Corporate Value}

The result of the fourth hypothesis analysis shows that Liquidity has no significant effect on Corporate Value. Liquidity position is not taken into account by investors in the liquidity ratio because only show the ability of the company to cover current liabilities with current assets of the company. In investing, investors not only review of how big the company is liquid but also from the other side such as the extent to which the company in generating profits that are reflected in the value of a company's profitability. This research is consistent with the research of Nurhayati (2013) which in her research obtained the result that Liquidity has no significant positive effect to Corporate Value [18]. However, the results of Putra and Lestari (2016) show that liquidity affects the value of the company [19].

\subsubsection{The Effect of Debt Policy on Corporate Value}

The results of the fifth hypothesis analysis obtained debt policy does not affect the value of the company. The results of this study indicate that debt policy cannot be a benchmark of the value of the company. This indicates that the increased use of a company's debt is not the only positive signal for investors. Debt use is used forfunding the company's operational costs in the business may not necessarily improve the performance of the company, it shows that the company has not been able to utilize the debt utilization as an optimal funding source for operational financing. The result of this research is consistent with research result of research of Pertiwi, Parengkuan, Tumiwa (2016) and Apsari, Idha (2014) stating that debt policy has no significant effect to company value [14], [25]. While the research result of Purnama (2016) shows the opposite, debt policy has a significant effect on company value [20].

\subsubsection{The Influence of Investment Decision on Corporate Value}

The result of the sixth hypothesis analysis shows that investment decision has positive significant effect to firm value. This is consistent with the signaling theory which states that investment spending gives a positive signal about future growth of the company, thus increasing the stock price as an indicator of corporate value. A high PER shows a good corporate investment so investors will be interested. This means the greater the investment made by a company, the higher the value of a company. With the investment, investors assume that in the future the profitability of the company will increase. Thus investors will be more interested in buying shares of companies that make investments, so this will lead to increased stock prices and will ultimately increase the market value of the company. The results of this study are consistent with the results of research from Pertiwi (2016), and 
Purnama (2016) which shows that investment decisions significantly affect the value of the company and inconsistent with research Languju (2016) stating that investment decisions do not affect the value of the company [20],[26].

\section{Conclusion}

Based on the research conducted, the conclusions obtained are as follows:

1. Profitability and Investment Decision has a significant effect on Corporate Value.

2. Leverage, Company size, Liquidity, and Debt Policy has no significant effect on Corporate Value.

\subsection{Managerial Implications}

In the study of profitability variables are proxied by using return on assets, and investment decisions proxied by PER, profitability variables and investment decisions have a positive effect on the value of the company. This shows that profitability and investment decisions become benchmarks that can determine the value of the company. The higher profitability a company gets then the better productivity of assets in obtaining profit. This will further increase the investor's appeal to the company. So that profitability becomes information that is considered important by investors to invest. High corporate value can prosper the shareholders or investors. So do investment decisions, investment decisions can give a positive signal about the company's growth in the future, thus increasing the stock price as an indicator of corporate value. A high PER shows a good corporate investment so investors will be interested. This means the greater investment made by a company, the higher the value of a company. With the investment, investors assume that in the future the profitability of the company will increase. Thus investors will be more interested in buying shares of companies that make investments, so this will lead to increased stock prices and will ultimately increase the market value of the company.

In this study, leverage, debt policy, firm size and liquidity have no significant effect on firm value. This implies that how much companies use debt-induced financing, the ability of companies to pay their current liabilities in the future, the size of the assets or resources of the company is not a consideration of investors in making investment decisions.

\subsection{Limitations of Research}

The following limitations in this study, are as follows:

1. This research only use independent variable that is profitability, leverage, company size, liquidity, and debt policy and investment decision.

2. The object of research consists of only 9 manufacturing companies in the sector of consumer goods sub sector food and beverages listed on the Indonesia Stock Exchange (BEI) which is sampled by the selection process according to certain criteria.

3. The five-year observation period from 2012 to 2016 , so it has not been able to see the long-term trend of corporate value change. 


\subsection{Suggestion}

The suggestions that can be taken into consideration in following up on matters relating to research are as follows:

1. It is recommended to multiply the number of subjects to be analyzed by adding other subsectors so that the results of research more generalizable.

2. It is suggested to add another variable to the research model, which may have a greater influence on the value of the firm. Such as dividend policy, managerial ownership, profitability, capital structure, earnings per share, and others.

\section{References}

[1]A. Munawaroh, "Pengaruh Kebijakan DividenPadaNilai Perusahaan.," J. Ilmu dan Ris. Akunt., Vol. $5,2014$.

[2]Harmono, Manajemen Keuangan. Jakarta: Bumi Aksara, 2011.

[3]K. Meidiawati, "Pengaruh Size, Growth, Profitabilitas, Struktur Modal, Kebijakan Dividen Terhadap Nilai Perusahaan,” J. Ilmu dan Ris. Akunt., vol. Vol. 5 No., 2016.

[4]R. Suffah and A. Riduwan, "Pengaruh Profitabilitas, Leverage, Ukuran Perusahaan dan Kebijakan Dividen Pada Nilai Perusahaan,” J. Ilmu dan Ris. Akunt., vol. Vol. 5 No., 2016.

[5]Kasmir, Analisis Laporan Keuangan. Jakarta: Rajawali Pers, 2015.

[6]I. Fahmi, Manajemen Keuangan Perusahaan dan Pasar Modal. Bandung: Alfabeta, 2013.

[7]A. Sugiono and E. Untung, Panduan Praktis dasar Analisa Laporan Keuangan. jakarta: Grasindo, 2016.

[8]Fakhrudin and K. Amalia, Kesulitan Keuangan Perusahaan dan Personal. Medan: USU Press, 2008.

[9]A. Sawir, Analisa Kinerja Keuangan dan Perencanaan Keuangan Perusahaan. Jakarta: PT. Gramedia Pustaka Utama, 2008.

[10]S. Hermuningsih, "Pengaruh Profitabilitas, Size Terhadap Nilai Perusahaan Dengan Struktur Modal Sebagai Variabel Intervening," J. Siasat Bisnis, Vol. 16 No, pp. 232-242, 2012.

[11]A. D. Rahmawati, Topowijono, and S. Sulasmiyati, "Pengaruh Ukuran Perusahaan, Profitabilitas, Struktur Modal Dan Keputusan Investasi Terhadap Nilai Perusahaan,” J. Adm. Bisnis Univ. Brawijaya, Vol. 23, 2015.

[12]R. Amanah, D. Atmanto, and D. F. Azizah, "Pengaruh Rasio Likuiditas dan Rasio Profitabilitas Terhadap Harga Saham,” J. Adm. Bisnis Univesrsitas Brawijaya, Vol. 12, 2014.

[13]Munawir, Analisis Laporan Keuangan, 4th ed. Yogyakarta: Liberty Yogyakarta, 2016.

[14]P. J. Pertiwi, T. Parengkuan, and J. R. Tumiwa, "Kebijakan Hutang, Keputusan Investasi dan Profitabilitas Terhadap Nilai Perusahaan Food and Beverages Yang Terdaftar Di Bursa Efek Indonesia," J. EMBA, Vol.4 No.1, pp. 1369-1380, 2016.

[15]S. Harjadi, Pasar Modal Indonesia Pengantar dan Analisis. Jakarta: In Media, 2013.

[16]U. Nadhiroh, "Studi Emiris Keputusan Deviden, Investasi, dan Pendanaan Eksternal pada Perusahaan Inodenia Go Publik di Bursa Efek Indonesia,” J. Oton., Vol. 13 pp. 91-104, 2013.

[17]E. P. Ta'dir, T. Parengkuan, and I. S. Taerang, "Struktur Modal, Ukuran Perusahaan dan Risiko Perusahaan Terhadap Nilai Perusahaan Otomotif yang terdaftar di BEI,” J. EMBA, Vol. 2 No 2, 2014.

[18]M. Nurhayati, "Profitabilitas, Likuiditas Dan Ukuran Perusahaan Pengaruhnya Terhadap Kebijakan Dividen Dan Nilai Perusahaan Sektor Non Jasa,” J. Keuang. dan Bisnis, Vol. 5, 2013.

[19]A. A. N. D. Putra and N. P. V. Lestari, "Pengaruh Kebijakan Dividen, Likuiditas, Profitabilitas dan Ukuran Perusahaan terhadap Nilai Perusahaan,” E-Jurnal Manaj. Unud, Vol. 5, pp. 4044-4070, 2016.

[20]H. Purnama, "Pengaruh Profitabilitas, Kebijakan Hutang, Kebijakan Dividen, dan Keputusan Investasi Terhadap Nilai Perusahaan,” J. Akunt., Vol.4, 2016.

[21]Suroto, "Pengaruh Keputusan Investasi, Keputusan Pendanaan dan Kebijakan Deviden terhadap Nilai Perusahaan (Studi Empiris pada Perusahaan LQ- 45 yang Terdaftar di Bursa Efek Indonesia," J. 
Ilm. UNTAG, Vol.4 No.3, 2015.

[22]F. Moniaga, "Struktur Modal, Profitabilitas dan Struktur Biaya Terhadap Nilai Perusahaan Industri Keramik, Porcelen Dan Kaca Periode 2007-2011,” J. EMBA, Vol. 1, 2013.

[23]Prastika, "Pengaruh Ios, Leverage, Dan Dividend Yield Terhadap Profitabilitas Dan Nilai Perusahaan (Sektor Manufaktur Di BEI)," J. Magister Manaj. Univ. Udayana, 2012.

[24]I. G. B. A. Pratama and I. G. B. Wiksuana, "Pengaruh Ukuran Perusahaan dan Leverage Terhadap Nilai Perusahaan Dengan Profitabilitas Sebagai Variabel Mediasi," E-Jurnal Manaj. Unud, Vol.5 No.2, pp. 1338-1367, 2016.

[25]A. Apsari and Idha, "Pengaruh Return On Equity, Net Profit Margin, Debt to Equity Ratio, dan Long Term Debt to Equity Ratio Terhadap Price Bool Value," Univ. Brawijaya. J. Adm. Bisnis, Vol. 27 No. Oktober 2015, 2014.

[26]O. Languju, "Return on Equity, Ukuran Perusahaan, Price Earnings Ratio, dan Struktur Modal Terhadap Nilai Perusahaan Pada Perusahaan Property and Real Estate yang terdaftar di BEI," J. Berk. Ilm. Efisiensi, Vol. 16, 2016. 